\title{
Safety in the use of car gas fuel installations
}

ARTICLE INFO

\section{Received: 7 July 2021}

Revised: 1 August 2021

Accepted: 12 September 2021

Available online: 17 September 2021
The safe use of gas fuel installations in vehicles is guaranteed by legal and technical aspects. These topics are included in this study. The regulations ensuring safety in the operation of the mentioned fuel systems serve as a solution for potentially hazardous situations. The components of propane-butane and CNG fueling systems are designed, manufactured and tested to maximize their safety of use. The regulations [6-8] define the guidelines for the arrangement and assembly method of the system components, and additionally, the assembly service itself may be performed only by an authorized workshop with granted permissions. Installations using gaseous fuels are safer than conventional fuels in the event of a collision or fire, as long as the user of the installation does not gross negligence in operation and maintenance. The article also discusses the context of the restriction in access to the car infrastructure for cars powered by gaseous fuels.

Key words: safety, gas, fuel, $L P G, C N G$

This is an open access article under the CC BY license (http://creativecommons.org/licenses/BY/4.0/)

\section{Introduction}

The safety of use of vehicles with gas fuel supply installations is influenced by at least several factors: meticulously constructed homologation regulations $[6,7]$ which force constructions and manufacturers to apply solutions ensuring safe use and correct installation of the installation, as well as proper operation and maintenance, the details of which are regulated by applicable regulations [8]. The absence of tragic accidents related to the use of propane butane Liquified Petroleum Gas (LPG) and Compressed Natural Gas (CNG) as engine fuels indicates that the designed system for approving and controlling automotive gas installations is working properly. Provisions in the Regulations 67 and 110 of the United Nations Economic Commission for Europe (UNECE), according to which gas supply systems are approved, minimize the possibility of hazardous situations related to their use and minimize negative effects in emergency situations, such as a collision. A number of selfacting safety devices make the use of a gas fueled car safe and in this respect the same as with conventional fuels.

\section{Installation components}

A CNG and LPG supply installations are usually alternative fueling systems for spark ignition and compression ignition engines, closely cooperating with the original fuel supply system. Regardless of the type of primary power supply system used, the gas system must meet its level of original solutions, both in terms of technical advancement, as well as safety requirements and exhaust emissions [4]. Gas systems are divided into those installed in the cars at the factory, installed as an additional power supply system, somewhat "next to" the original factory system and singlefuel systems (for example city buses powered by CNG) [1, 3]. There are great structural similarities in the construction of LPG and CNG installations [1]. Different types of gas installations generally use the same set of basic components conceptually: filler, tanks, pipes and fittings, components in the engine compartment.

\subsection{Gas fuel tanks}

Gaseous fuel tanks as devices operating with overpressure are subject to the obligation of technical inspection, and their use in cars means that they are built on the basis of detailed requirements contained in the type-approval regulations by UNECE. The safety of the exploited tank is guaranteed by the supervision carried out from the design stage to the obligation of technical inspections $[6,7]$.

Automobile LPG tanks are made of steel compliant with the EN 10120 standard. They are unalloyed steels with a maximum carbon content of up to $0.2 \%$. The materials used for LPG tanks can be successfully processed (also pressed). In the case of $\mathrm{CNG}$, due to the higher operating pressure, the fuel is stored in steel cylinders manufactured by stamping from a block and hot-drawing, or composite cylinders with or without a braid. Compressed natural gas storage tanks undergo a complex test cycle, including [2, 6, 7]:

- strength of construction material,

- hydraulic pressure test,

- fire test,

- tank impact resistance test (composite),

- bullet resistance (composite).

The parent material of the tank is subjected to tensile and bending strength tests. It consists in taking samples of materials from places strictly defined in the regulations. Gas tanks must show certain behavior in a strictly defined manner [3, 6].

The tanks are also burst tested by hydraulic pressure. The pressure during the test must be suitably built up, and its changes must be recorded over time. In practice, the burst pressure of the tank has much higher limits than those imposed by the regulations by UNECE. The working pressure in the tank during normal operation does not exceed $2 \mathrm{MPa}$ for LPG and in steel tanks $22 \mathrm{MPa}$, and in composite tanks 35 or even $70 \mathrm{MPa}$ for CNG [3, 6]. The tank must be burst after an appropriate increase in its volume, as specified in the regulations (from 8 to $20 \%$ depending on the type of the tank). A very important regulatory requirement 
is also the fact that when the tank ruptures, its fragmentation cannot occur (no fragments that could injure someone).

Each manufactured tank is subjected to a hydraulic pressure test. The test consists in filling the inside of the tank with liquid (usually water) and increasing its pressure to the value specified in the regulations. During its execution, the tank may not be permanently deformed or unsealed $[2,3,6]$. The purpose of the test is to check whether the tank with the mounted equipment will not burst as a result of the action of strictly defined fire conditions. The test is performed on a copy representing a given type of gas tank. During the test, the tank is equipped with full fittings. The tank is checked on the heat source located under the tank at a specific temperature. During the test, the temperature of the appropriate places in the mantle is measured [3, $6,9]$.

The effects of the shock resistance test, consisting in dropping an empty tank at an appropriate angle to the level from a strictly defined height, are presented below in Fig. 1 [4].

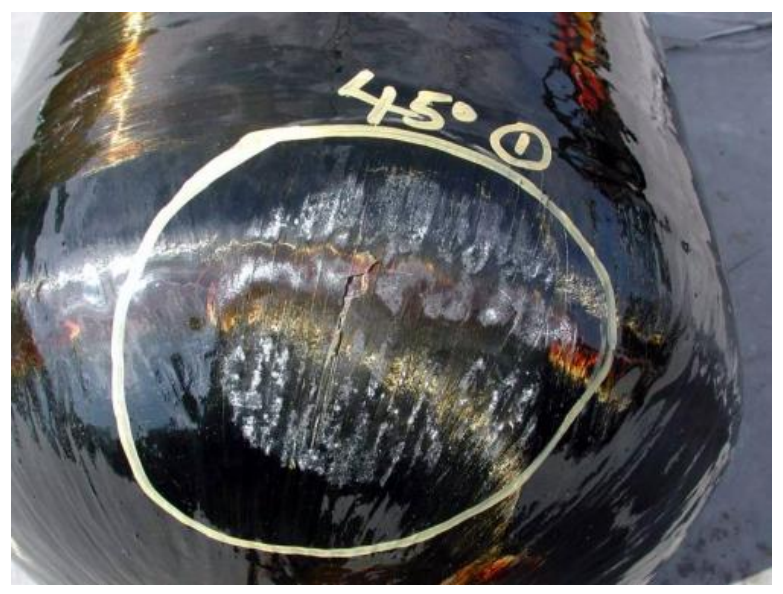

Fig. 1. The effects of the impact test of the CNG composite tank [12]

\subsection{Method of mounting tanks}

As the gas installation tank is its heaviest element, it is subjected to high inertia forces during a collision. During a rapid change of vehicle speed (e.g. during a collision with an obstacle), these forces try to tear the elements fastening the tank out of the place of assembly. During the collision there are very large deceleration, in the order of more than $20 \mathrm{~g}$. The risk of inertia is enormous, therefore the appropriate mounting of the tanks is regulated by the provisions of UNECE. Gas tanks must be installed with the use of appropriate bolts of strength class 8.8 . The fastening bolts are counted only for breaking, their shear is neglected due to the moment with which they are tightened and the resulting high friction occurring in the connection between the tank, its frame (Fig. 2) and the place of installation of the tank. If the tanks are fitted with fasteners welded to them, their welds must withstand the external forces of $30 \mathrm{~g}$ in all directions. The authors of the approval regulations assumed that the mounting of the tanks must withstand the load resulting from acceleration of $20 \mathrm{~g}$ (acting along the longitudinal axis of the car). In terms of transverse forces, the regulations say that the inertia forces resulting from acceleration of $8 \mathrm{~g}$ must be withstand by connecting the tank to the body. In the case of a $100 \mathrm{~kg}$ tank, this will correspond to a force of $8000 \mathrm{~N}$ acting on the tank as if its weight had increased to $800 \mathrm{~kg}$. Gas tanks must not be installed in the front of the vehicle and in the engine working space. It is allowed to mount the tanks on the vehicle roof $[4,11,12]$.

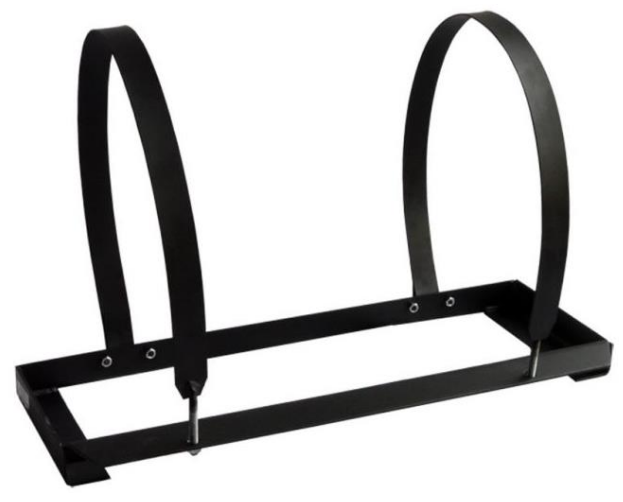

Fig. 2. A frame for a cylindrical LPG tank [9]

\subsection{Armature securing the tank}

„The $80 \%$ valve” is responsible for closing the gas supply during refueling at the fuel level corresponding to $80 \%$ of the geometric volume of the tank. This allows the space in the tank to be kept, giving the possibility of changing the LPG volume as a function of the ambient temperature. This valve is not used in CNG storage tanks. The operation of the $80 \%$ valve should be checked while refueling gaseous fuel. Overfilling the cylinder in the event of high ambient temperature may lead to activation of the safety valve $[2,6,7]$.

From April 1, 2002, after introducing amendments to the regulations by the UNECE, a safety valve is installed in all valve assemblies (aka multivalve). The tank is thus protected against excessive pressure build-up. The gaseous fuel is vented through the ventilation ducts connected to the housing. The gas phase of the fuel always escapes through the valves (safety and fire valves). Liquefied gas escaping through the valves, rapidly expanding, could cause the duct diameters to shrink through frost. Approval tests of the valve verify the correctness of its operation during 10,000 opening cycles without changing the operating characteristics $[3,6,7]$.

The increase in the temperature of the tank shell reduces the strength of the material from which it is made. With rapid temperature rise, the operation of the safety valve may not be sufficient to bring the pressure down to a safe level. The fire (fusible) valve opens when the tank shell reaches a certain temperature and drops it in order to avoid uncontrolled deformation or unsealing of the tank. The use of a fire valve is required if the safety valve has a capacity below $17.7 \mathrm{~m}^{3} / \mathrm{min}$. This parameter results from and is closely related to the surface of the tank $[4,7,12]$.

The overflow valve is activated if the gas flow is too intense (exceeding the engine demand of fuel), which may occur, for example, in the case of damage to the mechanical pressure line leading to the engine compartment. This valve is calibrated to operate when the differential pressure is approximately $90 \mathrm{kPa}$. The flowing gas "carries away" a mechanical element, most often a ball, which limits the gas flow to a level approximately equal to the engine's fuel requirement. In this way, the tank is protected against 
a sudden outflow of gas, which poses the risk of its damage and increases the risk of explosion [2].

An indicator placed on the tank (for CNG cylinders, a similar task is performed by a mandatory pressure gauge), cooperating with a float inside the cylinder. Its indications are "approximate" and are very important in emergency situations for emergency services to assess the amount of fuel in the tank. Installed in accordance with the guidelines, the tank must be placed in such a way that its filling level can be easily read $[2,6,7]$.

The operation of the working solenoid valve is determined by the operation of the engine. It closes when the engine RPM signal disappears. The necessity to use it results from the protection of gas flow in emergency situations, for example during a collision/road accident, when the engine is stopped without the will of the vehicle driver $[2,6,7]$.

The gas supply from the tank to the engine compartment, when it is required to unseal the high pressure system (during service works), is closed on the cylinder with a manual valve.

The gas flow towards the gas tank only when refueling is provided by a non-return valve (Fig. 3). Its construction uses a steel ball supported by a spring. These elements are located in the refueling channel. The pressure from the fuel dispenser moves the ball away from the valve seat and deflects the support spring. After the pressure drops from the distributor side, the ball is pressed against the seat. This way, the tank is protected against fuel leakage in the event of damage to the pipe from the refueling valve [2].

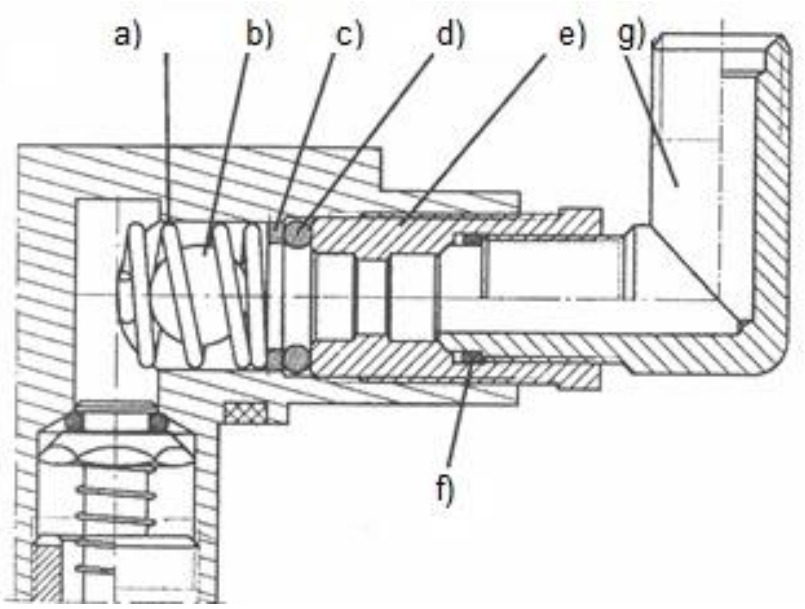

Fig. 3. Multivalve check valve [2]: a) spring, b) ball, c) washer, d) rubber sealing ring, e) reduction sleeve, f) rubber sealing ring, g) elbow fitting

The refueling valve is connected to the multivalve by a line that enables the refueling of gaseous fuel into the tank. Its construction also uses a non-return valve which prevents fuel from flowing out after refueling is finished. The LPG and CNG refueling valves are not compatible with each other (Fig. 4) [2].

All fittings of the LPG tank are placed in a gas-tight casing connected with ventilation ducts. When a leak occurs, the gas escapes through this system outside the vehicle, thus minimizing the risk of gas entering the passenger compartment of the vehicle $[2,6]$. a)

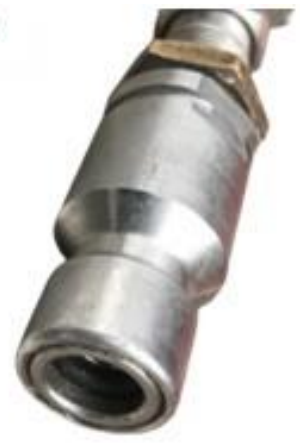

b)

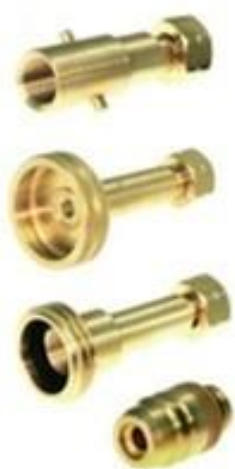

Fig. 4. Gas refueling valve: a) CNG, b) LPG - various types [11]

\subsection{Gas pipes}

Rigid metal or plastic pipes (also flexible) are used to connect automotive components of gas installations in which there is liquid gas. Metal pipes should be seamless, steel or copper (Fig. 5) for LPG and only steel for CNG. Steel pipes should be made of stainless steel or with additional anti-corrosion coating. Rigid pipes made of nonmetallic material may be used. The copper wires should be protected with a rubber or plastic cover along their entire length. The internal diameter of the rigid pipe should not exceed $12 \mathrm{~mm}$ when used with gaseous fuels, and the wall thickness should be at least $0,8 \mathrm{~mm}[6,7]$.

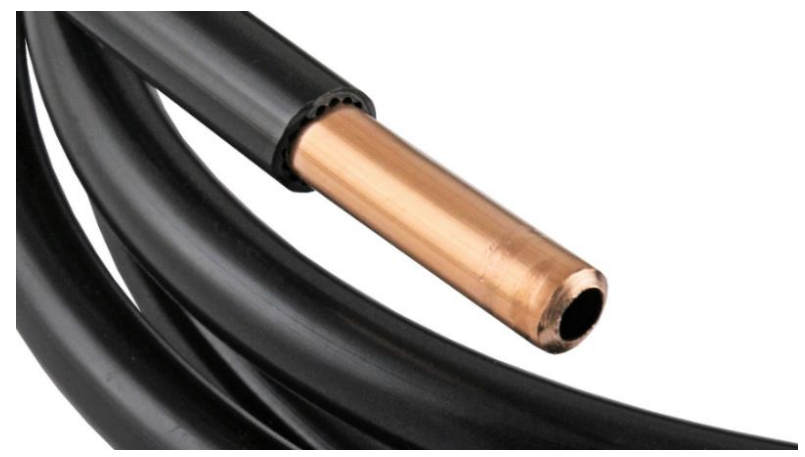

Fig. 5. Copper pipe for liquid gas fuel [11]

The requirements for flexible hose included in the regulations are very extensive and detailed. In the event of a road collision, when there is a movement of elements in the engine compartment, the priority is to avoid leakage of the gas installation, including its low-pressure part. The rubber gas pipes (Fig. 6) must consist of a smooth-walled inner tube (4) and a reinforced sheath with one or more intermediate layers (no. 1, 2, 3). If the reinforcement is made of anticorrosion materials, the shield (1) is not required [12].

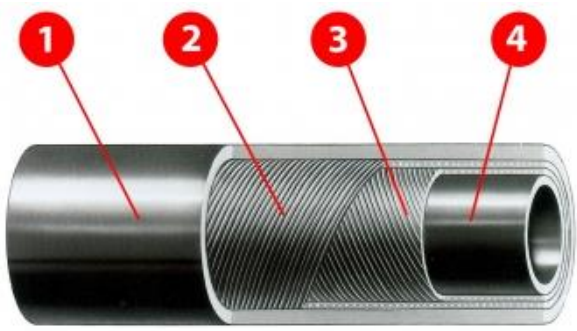

Fig. 6. Flexible fuel gas hose [12] 
The inner tube is in contact with the flowing gas. The material from which it is made must be neutral in terms of the action of hydrocarbons. There is a reinforcement in the gas line to maintain the internal bending section and resistance to internal pressure. Synthetic, metal or textile fibers are used in the reinforcement. The outer layer protects the cable against the conditions in the engine compartment and protects against mechanical damage. The inner tube and the sheath must exhibit tensile strength and must be able to achieve a total elongation of at least $250 \%$, according to ISO 37 . During approval, the cables are tested for bending resistance. A length of $3500 \mathrm{~mm}$ of wire is considered correct when it can withstand a bend test repeated 3000 times without breaking. After the bend test, the hose must withstand the internal pressure without showing any leakage $[1,6]$.

The provisions of the UNECE regulations define the requirements for low-pressure rubber hoses, which must withstand a maximum working pressure of $0.45 \mathrm{MPa}$ and the operating range at a temperature of -25 to $125^{\circ} \mathrm{C}$. The inside of the hose is tested for chemical resistance. It is immersed in n-pentane at a temperature of $23^{\circ} \mathrm{C}$ (according to ISO 1817) for 3 days. The change in the volume of the hose sample must not exceed $20 \%$, the change in tensile strength $-25 \%$, and the change in total elongation $-30 \%$. Then, after the cable has been stored in air at $40^{\circ} \mathrm{C}$ for 2 days, its weight is checked. The value, in comparison with the initial weight, cannot decrease by more than $5 \%$ $[4,11,12,18]$. The cable sheath (external part) is tested for resistance to n-hexane, in which the sample is kept at $23^{\circ} \mathrm{C}$ for 3 days. For sheaths, a greater tolerance of changes in mechanical parameters is allowed than for the internal part of the conduit: the maximum change in volume by $30 \%$, the maximum change in tensile strength by $35 \%$, and the maximum change in the total elongation by $35 \%$ [2, 3, 9]. The tightness test in accordance with the method described in ISO 4080 standard consists in connecting a $1000 \mathrm{~mm}$ long hose to a tank with liquid propane at a temperature of 23 $\pm 2^{\circ} \mathrm{C}$. The gas loss in the line is monitored for 2 days. A loss greater than $95 \mathrm{~cm}^{3}$ is not allowed [1,9]. Cables used in gas supply systems are also tested for fire resistance according to DIN 51622, DIN 12642 standards. It is required to maintain the ability to self-extinguish, and during their combustion they should not emit harmful substances $[1,9]$. Gas pipes according to ISO 1431/1 must pass the ozone shield resistance test. Samples stretched to $20 \%$ elongation are exposed to air with ozone content of $50 \mathrm{ppm}$ and temperature of $40^{\circ} \mathrm{C}$ for 5 full days. The samples should not show any cracks $[2,4,6,12]$.

The differences between the CNG and LPG lines appear in the context of the lines leading from the tank to the engine compartment. They result from the pressures at which propane-butane and $\mathrm{CNG}$ are stored. CNG requires stiff and more durable steel pipes (Fig. 7). The gas moving from the $\mathrm{CNG}$ cylinder to the engine still has a pressure several times greater than that of LPG, and any unsealing would be much more violent. Therefore, resistance to external factors as well as internal forces is important.

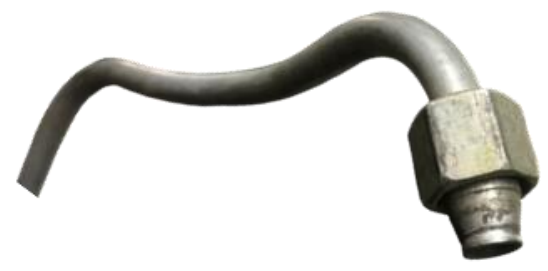

Fig. 7. High pressure CNG steel pipe

\section{Installation assembly}

\subsection{Arrangement of system components in the vehicle}

The provisions in the UNECE regulations, according to which gas supply systems are approved, regulate the position of the system components. In Polish law, annex 9 to the Polish ordinance of the Minister of Infrastructure on "technical conditions of vehicles and the scope of their necessary equipment" regulates the issues related to the installation of gas supply components, the operation of the vehicle with gas supply and its impact on the base fuel supply. The elements of the gas supply system should be arranged in a way that does not hinder the servicing of other car parts. The provisions of the annex concern the protection of gas system components (mechanical damage, corrosion), securing tanks against damage by cargo and that the installation should function properly and safely $[2,12]$.

In order to maintain the safe operation of the installation, the pipes should be arranged in a way that facilitates their inspection, so that they do not rub against the elements of the vehicle and at a distance of not less than $100 \mathrm{~mm}$ from the exhaust system, when a thermal screen is not used. Additionally, the cables must not run in the vicinity of the vehicle lifting points and their fixing must exclude the susceptibility of the cables to vibrations [2].

Gas pipes must not be welded, soldered or joined with snap joints. Standard self-clamping sockets are required to connect the wires, and the number of connectors should be kept to a minimum $[2,12]$.

Metal pipes connecting elements of the installation structure, which may be subject to a force displacing them during operation, should be shaped into loops with a radius of curvature adapted to the pipe diameter (due to the possibility of breaking) (Fig. 8) [2,8].

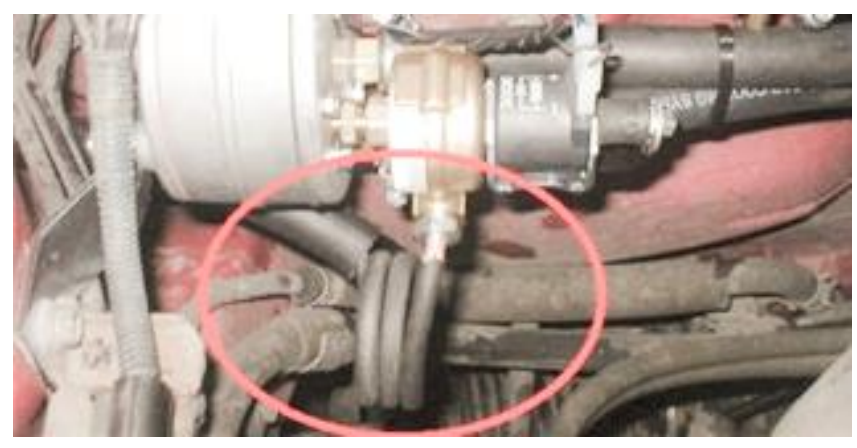

Fig. 8. The method of connecting the evaporator with a rigid copper LPG pipe

The cylindrical tanks can be mounted transversely or longitudinally with respect to the car axis (Fig. 9). The assembly rules apply to all LPG and CNG tanks installed in 
cars. Gas fuel tanks cannot be installed in the front of the car or in the engine compartment. They should be installed in such a way that the effects of collisions (mainly at the front and rear of the vehicle) are minimized $[2,8]$.

There should be no sharp or stiff elements in the vicinity of the installed gas tanks. If the tank is installed under the chassis, its distance from the engine exhaust system (without a heat shield) must not be less than $100 \mathrm{~mm}$. The ground clearance under the tank must not be less than $200 \mathrm{~mm}$.

The guidelines for the installation of gas system components in the engine compartment regulate the minimum distance of the reducer from the exhaust system to $100 \mathrm{~mm}$. The reducer should be installed in a place that is not exposed to temperature fluctuations (drops) while driving. In the vicinity of the reducer, in an easily accessible place, a gas solenoid valve is installed with the coil upwards. The requirement is to install the reducer in such a way that the car's movement does not affect its operation. The controller should be isolated from moisture and mounted away from strong heat sources such as the exhaust manifold or turbocharger. The installation of the gas controller and the wiring harness of the power supply system should be separated from the elements of the ignition system, as this may lead to interference $[2,2]$

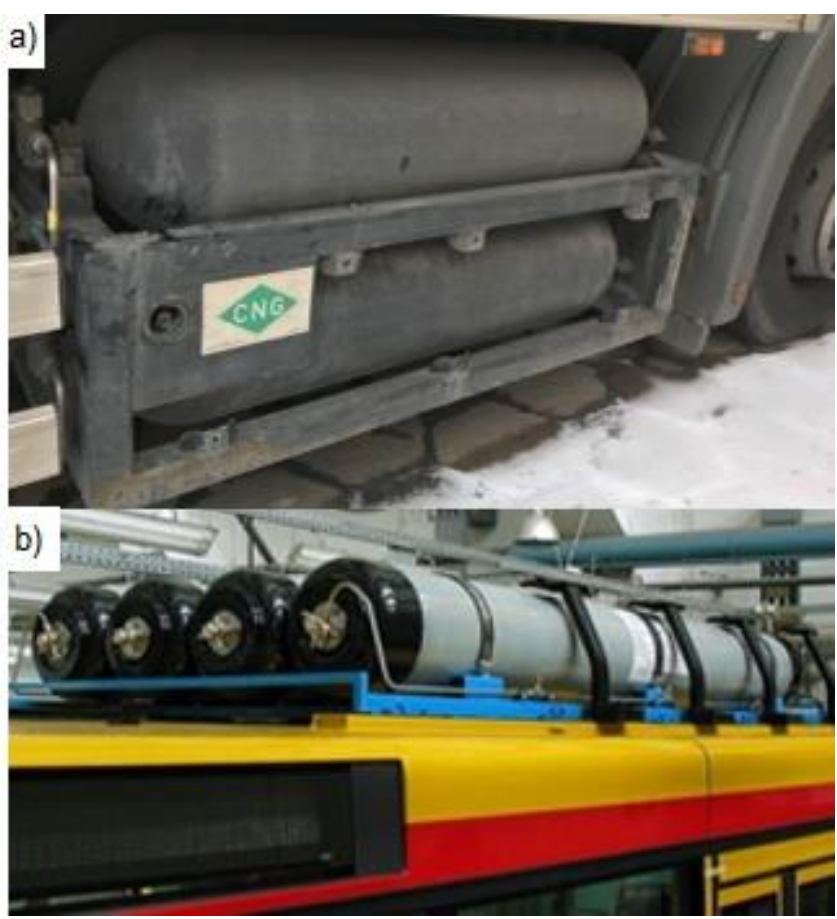

Fig. 9. Method of mounting CNG tanks: a) composite-aluminum ones on the frame of a truck; b) composite on the roof of a city bus [12]

\subsection{Homologation of the method of assembly of the installation}

In accordance with Polish law and the provisions of the Regulation of the Polish Minister of Infrastructure of December 24, 2003 on "the approval of the method of assembly of an installation adapting a given type of vehicle to be fed with gaseous fuel", installation services of this type of power supply may be performed by a company with a certificate of approval of the method of installation of gas supply systems it as part of the workshop dealer network.
The method of fuel system assembly adapting a given type of vehicle to gas supply, which is to be performed on the territory of the Republic of Poland, should meet certain technical requirements, the fulfillment of which is confirmed in the approval procedure of the installation method adapting a given type of vehicle to gas supply. The entity performing the installation of an installation adapting a given type of vehicle to run on gas may apply for the issue or amendment of a certificate of approval for the method of mounting an installation adapting a given type of vehicle to gas supply. The document is issued by the Polish Transport Technical Inspection Director by way of an administrative decision. The list of companies with approval and cooperating workshops is kept by the Polish Motor Transport Institute [2, 8].

\section{Gas installation during a road accident}

The discussed construction and legal requirements minimize the negative effects of a road accident in the context of equipping the car with a gas installation. The safety of passengers is ensured by both the functionality of the control electronics and the components made in terms of the materials used. The gas tanks are constructed in a way that ensures their safety in the event of a collision. Figure 10 shows the effects of a rearward collision with an LPGpowered vehicle. Additionally, according to the law, after each collision of a vehicle, they must undergo the legalization process again [2].

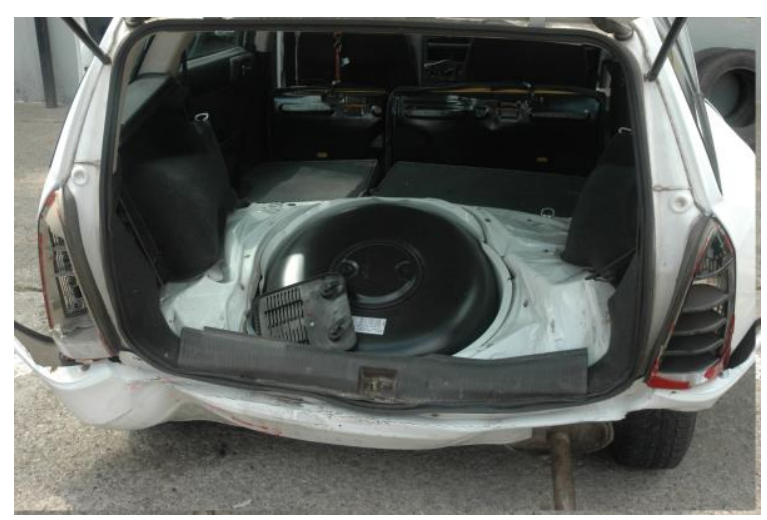

Fig. 10. The rear of a vehicle with a toroidal LPG tank after collision [12]

Connectors, nozzles and couplings are made of nonsparking materials (brass), so rubbing is not able to ignite any fuel vapors [11].

The gas ECU response time to switching off the gas installation is 0.3 seconds. The control electronics of the gas systems are designed in such a way that in the event of a sudden pressure drop in the system (e.g. after the fuel supply line to the reducer is broken), the system is immediately turned off and the engine is switched to the base fuel mode. Too low pressure in the system, determined on the basis of data from the gas pressure sensor, which is part of every modern gas installation, causes the gas supply to be disconnected. Therefore, the risk of leakage of the gas system in the engine compartment, and consequently the risk of gas leakage and ignition, is minimal. If, as a result of an accident, the gas flow from the tank to the engine compartment is disturbed (the fuel line is bent or broken), restarting 
the engine in gas mode will be impossible. Additionally, a solenoid valve in the engine compartment cuts off the flow of gaseous fuel when the engine (for whatever reason) is not running. The same mechanism occurs also when the fuel in the tank is exhausted - when the gas pressure drops (it stops flowing), the controller perceives it as a signal to turn off the system. Turning off the gas supply system also closes the solenoid valve on the tank, so the only gas that can leak from the vehicle is the one in the lines [4, 7, 12].

In the context of $\mathrm{CNG}$, it is also worth noting its physicochemical property in the form of low density under normal conditions (the density of natural gas is lower than that of air), thanks to which all leakages caused by the collision are released into the atmosphere, where they are quickly spread in the air without reaching the lower flammability limit. This further improves safety in the event of a collision.

Thanks to the security of the gas systems, damage to the gas supply system does not adversely affect the safety of the vehicle's operation.

\section{Danger during a fire in a car with a gas fuel system}

The fire test of an LPG fueled vehicle [13] carried out at the Polish Military Institute of Armament Technology in Zielonka (Poland) simulated a situation where, as a result of unsealing the gasoline tank and spilling fuel, it may ignite, which is tantamount to a car fire. The fire started at the rear of the vehicle due to the location of the gasoline tank. The gas tank was also installed in the rear part. During the fire test, there were about 25 liters of fuel in the gas tank, which accounted for $73 \%$ of its geometric capacity [11]. The fire was initiated with the use of gasoline in a container placed under the vehicle. The fire engulfed the entire rear of the car. After 5 minutes and 44 seconds, the gas tank fittings were activated. The cyclical operation of the safety valve lasted up to 9 minutes of the fire. The frequency of its operation (opening and closing) was initially increasing, and then the period began to lengthen to approx. 9 seconds, while the acoustic effect decreased. After the last closing of the safety valve in 9 minutes, the fire valve opened, as evidenced by the constant stoking of the flames and the characteristic, gradually decreasing in intensity, hiss of flowing gas, which ended 11 minutes and 30 seconds after the initiation of the test $[3,13]$.

The test showed that the LPG tank in a car poses no greater threat than a gasoline or diesel tank, and in some respects it is superior to them because it is a high-strength component. Gas tanks are more durable than conventional fuel tanks, which are most often made of plastic. The possibility of mechanical damage to the gas tank in the event of a fire is minimal. In the extremely unfavorable case of deformation of the tank shell, it is flexible enough (required by the production technology used) that it does not become unsealed. The high durability of the tank results from its operating conditions. Nominal pressure for LPG, depending on the degree of filling and the ambient temperature, ranges from 0.6 to $1.7 \mathrm{MPa}$. During the test, the pressure in the tank reached a value that allowed the safety valve to be opened (in LPG tanks - 2.7 MPa). The pressure increase takes place at a very high temperature, which at the same time weakens the material of the tank shell and its fittings. However, even such extremely unfavorable conditions did not cause the tank to become unsealed during the test. Releasing excess gas through the safety valve eliminated the increase in internal pressure in the tank. The fire gas escaping through the safety valves and the fire was removed through the vent under the car, which minimized stoking the flame $[12,13]$.

\section{Legal restrictions on a gas-powered vehicle}

Signs visible on public roads in Europe prohibiting the entry or parking of vehicles equipped with a gas installation (Fig. 11) are not included in the state's road traffic codes or in EU regulations. Therefore, the regulations do not regulate the liability for breaking it by the driver, there is no legal basis for issuing a fine for non-compliance with this and similar signs.

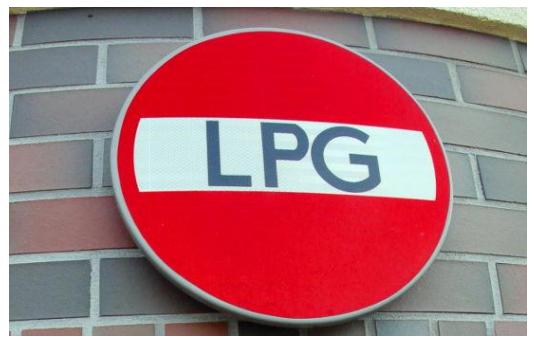

Fig. 11. A sign prohibiting entry for a vehicle powered by LPG

In Polish law, the document regulating the underground parking of a vehicle equipped with gas is the regulation of the Polish Minister of Infrastructure on the ventilation of parking lots. In those where cars powered by LPG and underground gas are parked, mechanical ventilation must be used, controlled by detectors of the unacceptable level of propane-butane gas concentration (Ministry of Infrastructure Regulation of 12 April 2002 on technical conditions that should be met by buildings and their location and its amendment of March 12, 2009). The LPG entry ban sign is not a grassroots initiative by the owners of underground garages. They are obliged to do so by $\S 4$ ust. 2 pkt. 5 of the Regulation of the Polish Minister of Interior and Administration of 7.6.2010 on fire protection of buildings, other construction facilities and areas, which says that: "owners, managers or users of buildings, storage yards and shelters, with the exception of single-family residential buildings: place, at the entrances to closed garages with the floor below the ground level, legible information on whether or not cars powered by LPG, propane-butane, referred to in technical and construction regulations, are allowed or not to park in these garages" The above-mentioned regulations refer to the information obligation and ventilation. The ban on entry may therefore only result from the regulations of the car park established by its owner.

Due to the lower density of natural gas than air, entry bans do not apply to vehicles powered by this type of gas fuel. CNG does not pose a fire hazard as it lies low next to the floor and in sewers.

\section{Conclusion}

Both legal, legalization and technical aspects guarantee the trouble-free and safe use of gaseous fuel in motor vehi- 
cles, as long as the user of the installation does not lead to gross negligence in operation and service. Gaseous fuels are safer than conventional fuels, and the ongoing development of the latest generation installations with direct gas fuel injection should, in the near future, support a stable growth in their use in the automotive industry, which will translate into a further increase in the safety of vehicle operation.

\section{Nomenclature}

CNG compressed natural gas

DIN Deutsches Institut für Normung (German Institute for Standardization)

EN European Norm Standards

ISO International Organization for Standardization

LPG liquefied petroleum gas

UNECE United Nations Economic Commission for Europe

\section{Bibliography}

[1] BIENIEK, A., GRABA, M., MAMALA, J. et al. Application of biogas to supply the high compression ratio engine. Combustion Engines. 2019, 179(4), 40-46. https://doi.org/10.19206/CE-2019-406

[2] GĘBUŚ, P. Niezbędnik diagnosty SKP 2020, SIMP AUTOMEX. Tarnów 2020.

[3] KNEBA, Z., STEPANENKO, D. DME as alternative fuel for compression ignition engines - a review. Combustion Engines. 2019, 177(2), 172-179. https://doi.org/10.19206/CE-2019-230

[4] MAJERCZYK, A., TAUBERT, S. Układy zasilania gazem propan-butan. Wydwnictwa Komunikacji i Łaczności. Warszawa 2003.

[5] SMIL, V. Natural Gas. Fuel for the 21st Century. Wiley. 2015.

[6] Regulation No 67 of the Economic Commission for Europe of the United Nations.

[7] Regulation No 110 of the Economic Commission for Europe of the United Nations.
[8] Dziennik Ustaw 2016 poz. 2022 - Obwieszczenie Ministra Infrastruktury i Budownictwa z dnia 27 października 2016 r. w sprawie ogłoszenia jednolitego tekstu rozporządzenia Ministra Infrastruktury w sprawie warunków technicznych pojazdów oraz zakresu ich niezbędnego wyposażenia.

[9] Rozporządzenie Ministra Infrastruktury z 12 kwietnia 2002 r. w sprawie warunków technicznych, jakim powinny odpowiadać budynki i ich usytuowanie i jego nowelizacja z 12 marca 2009.

[10] Rozporządzenie Ministra Spraw Wewnętrznych i Administracji z 7.6.2010 r. w sprawie ochrony przeciwpożarowej budynków, innych obiektów budowlanych i terenów.

[11] AC S.A. https://www.ac.com.pl (accessed on 3.09.2021).

[12] GAZEO.PL. https://www.gazeo.pl (accessed on 3.09.2021).

[13] Military Institute of Armament Technology. https://www.witu.mil.pl/www/witu_pl.htm (accessed on 3.09.2021).

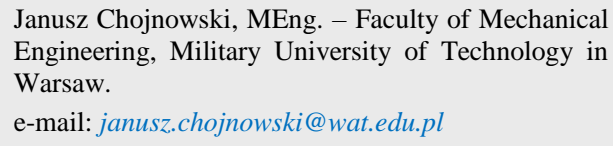

